\title{
E-Learning During Pandemic Covid-19 Era Drill Versus Conventional Models
}

\author{
https://doi.org/10.3991/ijep.v11i3.16505
}

\author{
Padrul Jana $(\bowtie)$, Nurchasanah \\ Universitas PGRI Yogyakarta, Bantul, Indonesia \\ padrul.jana@upy.ac.id \\ Syita Fatih 'Adna \\ Universitas Pekalongan, Pekalongan, Indonesia
}

\begin{abstract}
Coronavirus Disease 2019 (COVID-19) had been stated by the World Health Organization (WHO) as a pandemic. As a consequence, all teaching and learning processes had been conducted through e-learning. Although elearning, some of the teachers still used conventional models. They only sended material files and questions to students. Mathematics learning like this certainly did not give students enthusiasm for learning. Moreover, students are not used to getting various questions. Students had difficulty working on material development questions. This could be because conventional learning did not hone the ability to think reflective. For that reason, this research aimed at testing the computer-based drill learning and the conventional learning model through e-learning. The aspect that would be measured was the students' mathematical reflecting thinking. The research method was quasi-experimental by employing the pretest before the treatment and the posttest after the treatment. The research design employed two classes, the 26 students of the control class and 24 ones of the experiment class. The result revealed that a computer-based drilling learning model would be effective if it was viewed from the perspective of students' mathematical reflective thinking ability. On the other hand, the conventional learning model would not be effectively viewed from students' mathematical reflective thinking. This study's main contribution was the results of testing a learning model suitable for use during the Covid-19 pandemic. The results could be used by mathematics teachers in online learning at schools during a pandemic.
\end{abstract}

Keywords - Mathematical reflective Thinking, Drill Learning Model, Conventional Learning Model, E-learning

\section{Introduction}

At the beginning of 2020, the World Health Organization (WHO) had decided that Coronavirus Disease 2019 (Covid-19) was the global pandemic [1]-[4]. Consequently, Indonesia had declared a national disaster and stated the required acts to prevent the virus from spreading [5]. One of the virus's impacts was that the teaching and learning processes had been conducted from home or learning from home. There was a 
significant change in the process of learning. It forces us to transform all processes of learning, from the model of face to face in a classroom to the e-learning model. The vast development of technology and broad internet coverage support the educational sector to develop e-learning [6]. E-learning was learning that utilizes information technology in the learning process. The change process of the whole learning would change the way to learning process would be conducted.

E-learning was also applied to SMP Muhammadiyah 3 Yogyakarta. Of course, not all teachers were ready with online learning models. Based on observations, some teachers tended to use conventional learning. Even though the implementation was online, teachers still used conventional learning. The teacher only sended material files and questions to students. The teacher explained the material then gives evaluation questions according to the example questions. Mathematics learning like this certainly did not give students enthusiasm for learning.

Conventional learning tended to be teacher-centered. Students easily forgot the material that had been passed. Moreover, students were not used to getting various questions. Students had difficulty working on material development questions. This could be because conventional learning did not hone the ability to think reflective. The ability to think reflective was a directed and precise process in which individuals interpret, identify, analyze, evaluate, and draw conclusions in solving a mathematical problem. The ability to think reflective could develop if students are accustomed to being faced with practice questions.

One learning model that emphasizes guided practice was the drill learning model. The drill learning model was a learning model that focuses on providing guided questions to students. By using the drill learning model, students were accustomed to working on everyday problems and questions on material development. Student interest and achievement could increase [7] - [9]. This was because drill learning could hone students' motor and mental abilities [10]. Students who were often honed in motor and mental abilities could of course improve their learning achievement.

In this study, two learning models were used: the conventional learning model and the drill learning model. Based on Nida's research, with a face-to-face drill model, $85 \%$ of students achieve completeness. Conventional learning models could also achieve learning mathematics goals if taught or applied in the classroom [11]. This happens because, in this learning model, a teacher was free to convey complete information to foster student interest in learning material. However, in this study, both conventional and drill learning models used computer assistance.

Due to the pandemic of Covid-19 and the force to conduct teaching and learning processes through e-learning, the researchers tested those two learning models. The drilling model was equipped with a computer during the teaching and learning processes. Meanwhile, conventional learning was still teacher-centered during the process of transferring the learning material. It becomes crucial since e-learning is a new thing during the pandemic of Covid-19. It needs us to find a proper formula to teach to make students understand mathematics as a whole, although it is learning from home.

The mathematic reflective thinking abilities would be assessed and measures on those two learning models. It is expected that e-learning can grow students' ability to think carefully, full of consideration, sustainable and precise in facing particular 
mathematical problems [12]. It is expected that students could get a full and comprehensive understanding of Mathematics [13]. The indicators which show us mathematical reflective thinking were: (1) interpreting a particular case based on the complicated mathematical concepts, (2) identifying the mathematical concepts or formulas in a complicated mathematical problem, (3) evaluating/checking the validity of an argument based on the characters or concepts which are employed, (4) differentiating the data which are relevant and irrelevant, (5) drawing analogy from two identical cases, and (6) generalizing by providing reasons [14]. The novelty in this research is the use of the learning model. They were named using the Drill model, and the conventional model has done entirely online. By carrying out complete online learning has never been done before the Covid-19 pandemic.

\subsection{Research hipotesis}

In this study, it was necessary to think more about the influence of conventional learning models and computer-assisted drills on mathematical reflective abilities. So that the research aimed to find out (1) whether computer-assisted Drill model learning was effective for students 'mathematical reflective thinking skills, (2) whether conventional model learning was effective against students' mathematical reflective thinking skills, (3) whether computer-assisted Drill models for thinking skills reflective mathematical students were more effective when compared to conventional models.

\section{$2 \quad$ Method}

\subsection{Time, place dan research variability}

This research was conducted in April, the even semester of the 2019/2020 school year. The place of this research is SMP Muhammadiyah 3 Yogyakarta, which is located on Jl. Kapten Piere Tendean No.19, Wirobrajan, Yogyakarta City. This research population was all students of class VII SMP Muhammadiyah 3 Yogyakarta, which consisted of 8 classes. Then the sample was obtained through the cluster random sampling technique. Cluster random sampling was used because each class had a group that is considered homogeneous. The sample consisted of two classes, namely class VII A as the experimental class and VII B as the control class [15]. The experimental class had 24 students and the control class had 26 students. The experimental class was given the treatment of the computer-assisted drill learning model, while the control class was given the treatment of the computer-assisted conventional learning model. This study's independent variable was the learning model, which is categorized as the computerassisted drill learning model and the computer-assisted conventional model. Meanwhile, the variable that was influenced by this research was the ability to think mathematically reflective. 


\subsection{Research design, data collection technique, and instrument}

This study's research design was Quasi-Experimental (The Nonequivalent Control Group Design) with experimental and control classes [16], [17]. The research steps undertaken include:

1. Determine the research population, namely students of class VII SMP Muhammadiyah 3 Yogyakarta.

2. Determining the research sample using cluster random sampling technique to determine the control class and experimental class.

3. Arrange the instrument observation sheet and test instrument (pretest and post-test).

4. Perform test instrument validation.

5. Analyze test reliability.

6. Taking the initial data, namely the pretest which is in accordance with the indicators of mathematical reflective thinking skills.

7. Treating the drill learning model in the experimental class and conventional models in the control class.

8. Retrieve final data (Post-test)

9. Analyzing the prerequisites for the parametric statistical hypothesis testing (normality test and homogeneity test, both pre-test and post-test), if not met, then hypothesis 1,2 , and 3 testing will use non-parametric statistics.

\section{Hypothesis Test 1}

H_0: $\mu \_1=\mu \_2$ (computer-assisted Drill model learning was not effective for students 'mathematical reflective thinking skills).

H_ $1: \mu \_1 \neq \mu \_2$ (computer-assisted Drill model learning was effective for students 'mathemati-cal reflective thinking skills).

$\mu \_1$ : the mean value of the pre-test drill model; $\mu \_2$ : the mean value of the post-test drill model.

\section{Hypothesis Test 2}

H_0: $\mu \_1=\mu \_2$ (conventional computer model was not effective against mathematical reflective thinking skills).

H_1: $\mu \_1 \neq \mu \_2$ (conventional computer model was effective against mathematical reflective thinking skills)

$\mu_{-} 1$ : the mean value of the pre-test model conventional; $\mu \_2$ : the mean value of the post-test conventional model.

\section{Hypothesis Test 3}

H_0: $\mu \_1=\mu \_2$ (There was no difference in the mathematical reflective thinking ability of students who get computer-assisted Drill model learning compared to those who get conventional model learning).

H_1: $\mu \_1 \neq \mu \_2$ (There were differences in students' mathematical reflective thinking abilities who get computer-assisted Drill model learning compared to those who get conventional model learning).

$\mu_{-} 1$ : the mean value of the post-test drill model; $\mu \_2$ : the mean value of the post-test conventional model. 
10. Compile research results

The data collection techniques used were observation and tests. Observations were made to obtain data on teacher and student activities, as well as teacher learning implementation. The test was conducted to obtain data on the ability to think thematically through the pretest and posttest.

Table 1. Design analysis

\begin{tabular}{|l|c|c|c|}
\hline \multicolumn{1}{|c|}{ Class } & Pretest & Treatment & Posttest \\
\hline Experiment & $\mathrm{O} 1$ & $\mathrm{X} 1$ & $\mathrm{O} 2$ \\
\hline Control & $\mathrm{O} 3$ & $\mathrm{X} 2$ & $\mathrm{O} 4$ \\
\hline
\end{tabular}

With

$\mathrm{O} 1$ and $\mathrm{O} 3=$ Pretest

$\mathrm{X} 1=$ treatment of the experimental class using computer-assisted Drill models

X2 $=$ treatment of the experimental class using computer-assisted conventional models

$\mathrm{O} 2$ dan $\mathrm{O} 4=$ Posttest
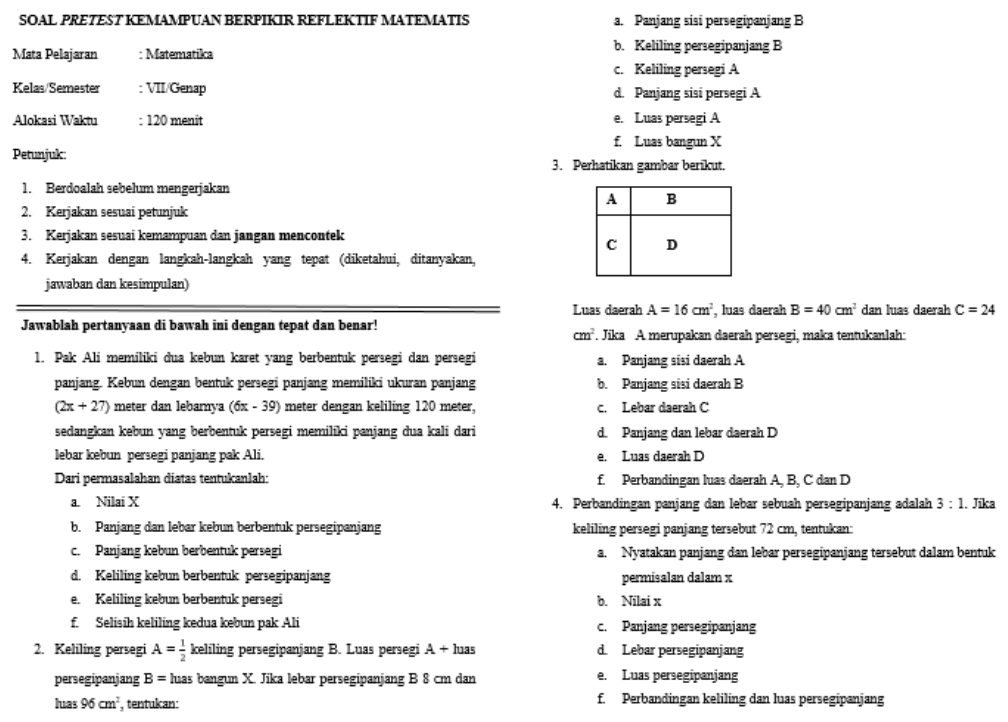

Fig. 1. Pretest question for the experiment and control class 

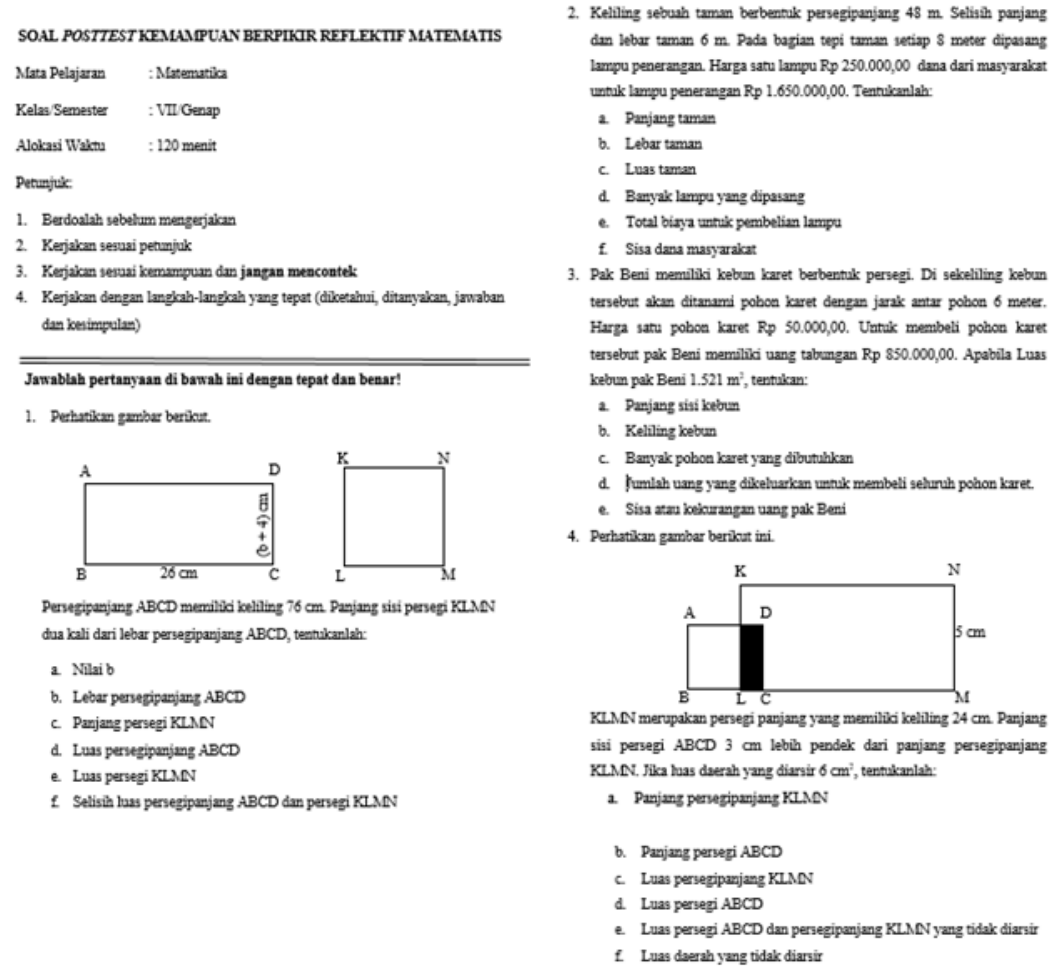

Fig. 2. Posttest question for the experiment and control class

Based on figure 1 and figure 2, the pretest for the experimental class was the same as for the control class. Posttest questions for the experimental class are the same as for the control class. In the experimental class, a pretest was given before being given the drill learning model. In the pretest and posttest questions, pay attention to indicators of reflective thinking skills.

\subsection{Data analysis technique}

Data analysis techniques which used were: (1) testing the instrument using reliability and validity testing, (2) testing the assumption through normality and homogeneity [18], and (3) testing the hypothesis using parametric statistics or statistics of nonparametric by considering the assumption test. There were two validity testing steps; those were logic validity (expert judgment) and empirical validity [19], [20]. Alpha Cronbach was used as an instrument of reliability testing [21].

As a prerequisite for hypothesis testing, the data were normally distributed and the data have the same variants. The test statistic used to test for normality is KolmogorovSmirnov. Meanwhile, the Levene statistic is used as an approach to the homogeneity test. If the test did not meet the prerequisites for testing the hypothesis, then the 
hypothesis test used nonparametric data analysis. The data analysis technique used to test the hypothesis if it meets the prerequisites for testing the hypothesis includes:

The first hypothesis test statistics was $t_{\text {count }}=\frac{\bar{X}-\mu_{0}}{s / \sqrt{n}}$

with the research hypothesis, the computer-assisted Drill model is effective on mathematical reflective thinking skills

The second hypothesis test statistic was $t_{\text {count }}=\frac{\bar{X}-\mu_{0}}{s / \sqrt{n}}$

with the research hypothesis, the computer-aided conventional model was effective on the ability to think mathematically reflective

The third hypothesis test statistic was $t_{\text {count }}=\frac{\overline{X_{1}}-\overline{X_{2}}}{s_{\text {combined }} \sqrt{\frac{n_{1}-n_{2}}{n_{1} \cdot n_{2}}}}$

With the research hypothesis, the mathematical reflective thinking ability of students who got computer-assisted Drill model learning was more effective than those who got conventional model learning.

The data analysis technique used to test the hypothesis if it did not meet the prerequisites for hypothesis testing includes. The first and second hypothesis test statistics, used the paired two-sample Wilcoxon ranking test. The Wilcoxon ranking test was $Z=$ $\frac{T-\sigma_{T}}{\sigma_{T}}=\frac{T-\frac{N(N+1)}{4}}{\sqrt{\frac{N(N+1)(2 N+1)}{24}}}$. Meanwhile, the statistical test for the third hypothesis was the Wald-Wolfowitz Test. The Wald-Wolfowitz statistical test was $Z=\frac{r-\mu_{r}}{\sigma_{r}}=\frac{r-\left(\frac{2 n_{1} n_{2}}{n_{1}+n_{2}}+1\right)-0,5}{\sqrt{\frac{2 n_{1} n_{2}\left(2 n_{1} n_{2}-n_{1}-n_{2}\right)}{\left(n_{1}+n_{2}\right)^{2}\left(n_{1}+n_{2}-1\right)}}}$.

\section{$3 \quad$ Results}

\subsection{Description of the research process}

In this pandemic of COVID-19, we were forced to conduct e-learning, a concept or media that we call studying from home. Concerning e-learning, this research uses online platforms such as WhatsApp and zoom. The experiment and the control classes were grouped into two e-learning classes, facilitated with the WhatsApp group and zoom application. Every e-learning class consists of students as a research subject, two observers, a teacher class, and the researchers. The observer assesses the learning process that had been designed or planned. Researchers and the teacher class were the agents who take full responsibility for teaching and learning in the class.

Before the teaching and learning process was conducted, both e-learning classes (class A as the experimental and class $\mathrm{E}$ as the control class) were treated with the essay as the pretest based on students' ability to think reflective. It was given to reveal the mathematical reflective thinking ability before the treatment. Table 2 reveals the mean score of the pretest from both e-learning classes. 
Table 2. Mean score of the pretest of the e-learning classes

\begin{tabular}{|l|c|c|}
\hline & Experiment Class & Control Class \\
\hline Score & 63,67 & 71,94 \\
\hline Criteria & Fair & High \\
\hline Amount of students & 24 & 26 \\
\hline
\end{tabular}

The pretest showed us that the control class possesses a better ability to think mathematically reflective than the experimental class. The experimental class was in fair criteria; meanwhile, the control had a high score. This was interesting since the experimental class will be treated by using a computer-based drilling learning model. Figure 3 was an example of a student's answer in the experimental class.

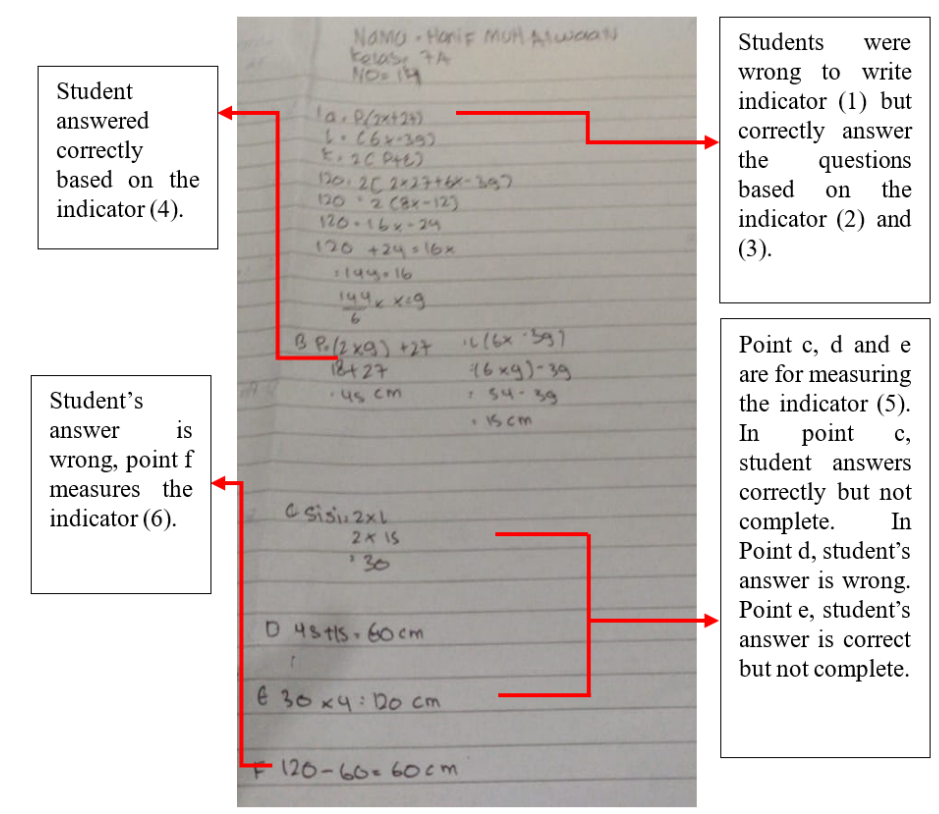

Fig. 3. Student's answer sheet in the experimental class

Based on Figure 3, the results of student work were analyzed using indicators of reflective thinking skills. Problem point a was used to measure indicators (1), (2), (3). In student work, point a showed that students did not write down indicators (1), but direct answered used indicators (2) and (3) correctly. Whereas in point b, student could answer correctly according to indicator (4). Problem points c, d, and e were used to measure indicator (5). In point c, student answered correctly but not complete. In Point $\mathrm{d}$, student's answer was wrong. Point e, student's answer was correct but not complete. The problem in point $\mathrm{f}$ was used to measure indicator (6), but students did it wrong.

The answer to the mathematical problems in the experimental class in figure 3 depicts that students made errors in some mathematical reflective thinking abilities indicators. Few of them answered closely to correct, but not complete to write the answer. 
This becomes our consideration since, in e-learning, most errors were produced during answer the question or solve the problems before the treatment. It was confirmed by the mean scores of the pretest in the experimental class as much as 65,1 in which it was in the fair category.

Figure 4 depicts the answer to the student's answers from the control class. It was seen that students in this class were better than other students in the experimental class in answering the pretest. See that there were 7,26 different points better than the experimental class. The student's pretest answers were wrong only on indicator (1) and (6).

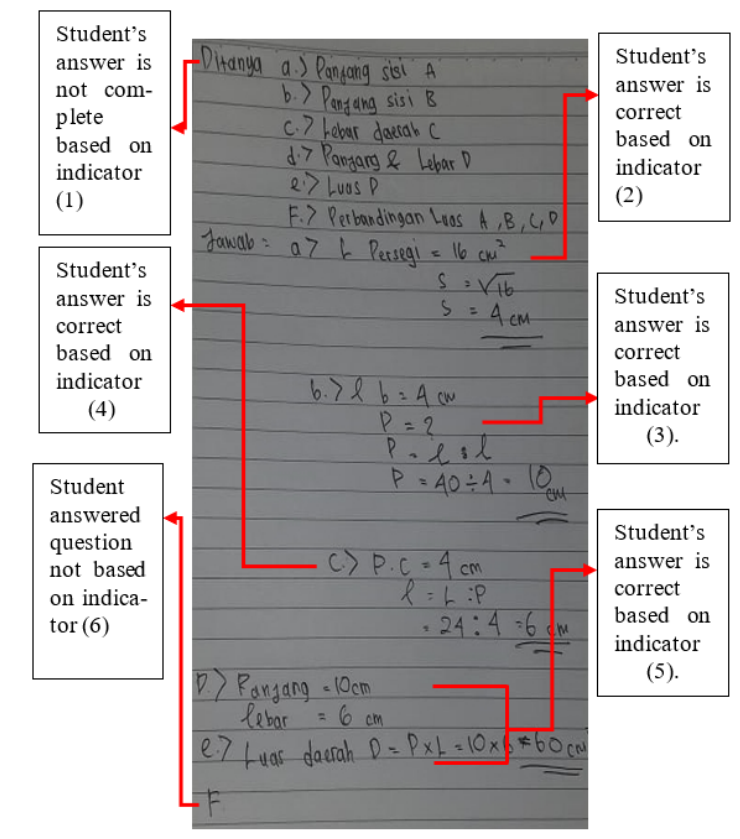

Fig. 4. Pretest answers of the student of the control class

Figure 4 showed the pretest results of one of the students in the control class. Based on the results of the student's writing on the thing being asked, students had not written complete indicator (1). Problem a was used to measure indicator (2). Problem b was used to measure indicator (3). Problem c was used to measure indicators (4). Questions $\mathrm{d}$ and e were used to measure indicator (5). Problem $\mathrm{f}$ was used to measure indicator (6). The results of the analysis showed that the students were correct in answering according to indicators (2), (3), (4), and (5). But in question f, students had not done it, so it was not according to indicator (6).

After the pretest, both classes of experimental and control would be treated differently. In the experiment, in learning, students would get the learning steps based on the syntax drill model based on the computer. Meanwhile, the control class would be treated based on the conventional syntax model in learning. The process of learning in both classes used e-learning through WhatsApp and zoom. We consider that two 
observers would observe learning to guarantee the quality process of teaching and learning. Table 3 depicts the mean percentage of teaching and learning in experimental and control classes.

Table 3. The Mean of Learning Implementation

\begin{tabular}{|l|c|c|}
\hline & \multicolumn{2}{|c|}{ Learning Model } \\
\hline & Computer-Based Drill Model & Conventional Model \\
\hline Mean Scores & $96,73 \%$ & $93,33 \%$ \\
\hline
\end{tabular}

Table 3 reveals the implementation of teaching based on the drilling model supported by computer is higher than the conventional one. It happens because the conventional model employs the teacher as the center of teaching and learning processes. Figure 5 is the computer display that supports the drilling model of teaching activities.

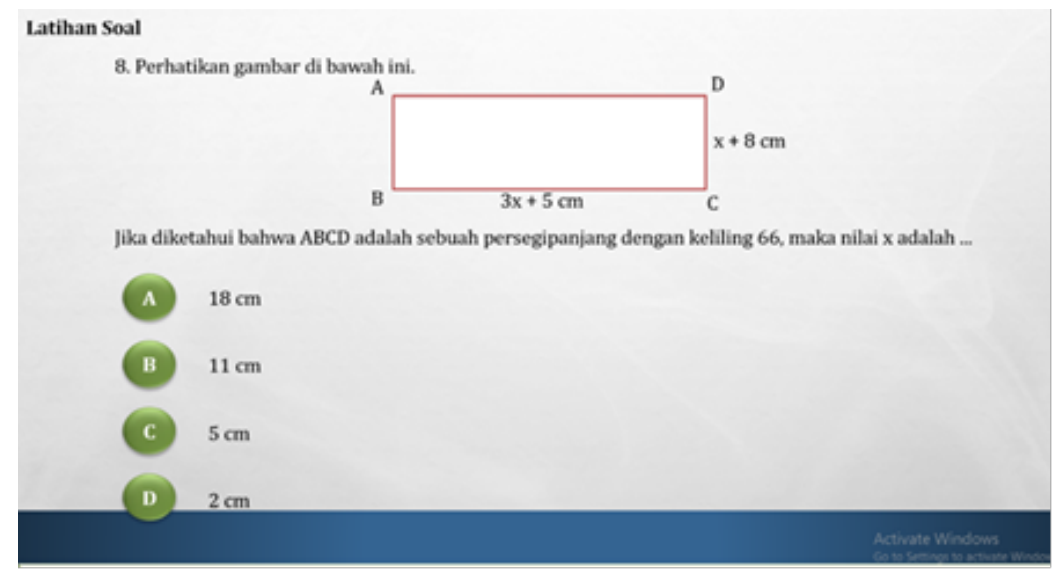

Fig. 5. Computer display of the drilling model

Figure 5 displays students' computers using the drilling learning model, and it is the multiple choices. Students are encouraged to finish the mathematical problems structurally and measurable based on mathematical reflective thinking abilities.

The posttest was the second step to reveal the differences between control and experiment classes. The posttest employed four essays that measure mathematical reflective thinking abilities. The researchers picked the essay to explore students' abilities in Math. Table 4 depicts the mean scores of both e-learning classes. 
Table 4. Mean Scores of the e-learning posttest

\begin{tabular}{|l|c|c|}
\hline & \multicolumn{2}{|c|}{ e-learning classes } \\
\hline & Experimental Class & Control Class \\
\hline Scores & 79,63 & 69,02 \\
\hline Criteria & High & Fair \\
\hline Amount of students & 24 & 26 \\
\hline
\end{tabular}

The result of the posttest was the reverse of the pretest. The score increases from the pretest to the posttest in the experimental class, and it was high. In the control class, it decreased from pretest to posttest, and it was fair.

\subsection{Research instrument analysis}

The pretest and the posttest were validated before they are used for this research. Two steps are employed to validate the pretest and posttest. Those were the logic and empirical validations. Instrument logic validity was conducted based on the expert's consideration related to the instrument that has been designed. It was resulted in the validity of the pretest and posttest essays to measure students' validity and reflectivity. It could be used with less revision. Empirical validity was gained through the momentum of product correlation, as shown in the below table 5 .

Table 5. Empirical Validity Result of the Pretest and Post-test Material

\begin{tabular}{|c|c|l|c|l|}
\hline Number & Pretest & \multicolumn{1}{|c|}{ Criteria } & Postest & \multicolumn{1}{|c|}{ Criteria } \\
\hline 1 & 0,603 & Valid & 0,737 & Valid \\
\hline 2 & 0,840 & Valid & 0,888 & Valid \\
\hline 3 & 0,809 & Valid & 0,857 & Valid \\
\hline 4 & - & - & 0,877 & Valid \\
\hline
\end{tabular}

It was found that three essays of the pretest and four essays of the posttest that have been tested and counted for the momentum product correlation are all valid. Then, the valid essays would be reliability tested using Alpha Cronbach. Table 6 below was the result of the reliability testing calculation of the pretest and the posttest.

Table 6. Pretest and Post-Test Material Reliability Test

\begin{tabular}{|l|c|c|}
\hline & Pretest & Postest \\
\hline CronbachAlpha & 0,614 & 0,847 \\
\hline Internal Consistency & acceptable & Good \\
\hline
\end{tabular}

The pretest material was in the category of acceptable, and the posttest was at one level higher. It was good. Tables 5 and 6 of the pretest and the posttest depict us that they were qualified for validity and reliability, meaning that the instruments could be used to measure students' ability to think reflectively. 


\subsection{Prerequisite test (assumption)}

On behalf of the data variant from the data samples used in the research, we need to conduct the homogeneity test, which uses the Levene's Test. Table 7 below reveals the result of the homogeneity test.

Table 7. Homogeneity Test Result

\begin{tabular}{|l|c|c|}
\hline \multicolumn{1}{|c|}{ Test } & Levene Statistic & Sig. \\
\hline Pre test & 2,492 & 0,121 \\
\hline Post Test & 0,033 & 0,858 \\
\hline
\end{tabular}

In table 7, it gains the sig. values $0,121>0,05$ which made the experimental and control classes pre-test were homogeny. Then value $0,858>0,05$ which made the experimental and control classes post-test were homogeny. It meaned that the students' reflective thinking ability between experimental and control groups was not different statistically. It enable us to treat them differently in the learning model testing.

The second prerequisite was the data normality testing. It employs Kolmogorov Smirnov Testing. Table 8 below reveals us the result of gain data of normality testing.

Table 8. Normality Testing Result

\begin{tabular}{|l|c|c|c|}
\hline \multicolumn{1}{|c|}{ Test } & \multicolumn{2}{c|}{ Kolmogorov-Smirnov } \\
\cline { 2 - 4 } & Statistic & Df & Sig. \\
\hline Pre-Test Experimental Class & 0,247 & 24 & 0,001 \\
\hline Pre-Test Control Class & 0,203 & 26 & 0,007 \\
\hline Post-Test Experimental Class & 0,184 & 24 & 0,034 \\
\hline Post-Test Control Class & 0,247 & 26 & 0,000 \\
\hline
\end{tabular}

Table 8 reveals Sig values. If it was compared to the alpha value of 0,05 , it gained $\operatorname{sig}<0,05$, which means that $\mathrm{H} 0$ was refused. It could be concluded that the data experimental and control classes were not normally distributed. The next was the testing effectiveness model of drilling learning with computer-based using statistics of nonparametric.

\subsection{Hypothesis testing}

In this part, the online effectiveness testing towards the computer-based drilling and the conventional model was conducted. Since the distributed data was not normal, the testing would be conducted using nonparametric statistics with the ranking testing method marked by the Wilcoxon Signed Ranks Test. The pretest and posttest data results were used to t-test the effectiveness of both online classes. 
Table 9. The result of effectiveness testing of the computer-based drilling learning model

\begin{tabular}{|l|c|}
\hline \multicolumn{1}{|c|}{ Wald-Wolfowitz Test } & Posttest - Pretest \\
\hline$Z$ & $-3,114$ \\
\hline Asymp. Sig. (2-tailed) & 0,002 \\
\hline
\end{tabular}

Table 9 reveals that the $\mathrm{Z}$ value is $-3,114$ since the $\mathrm{Z}$ is in the area of $\mathrm{H} 0$ refusal. It could be concluded that the drilling model of computer-based was effective for mathematical reflective thinking ability. Table 10 reveals to us the result of Wald-Wolfowitz's result in the control class.

Table 10.

The results of the conventional model learning effectiveness test

\begin{tabular}{|l|c|}
\hline \multicolumn{1}{|c|}{ Wald-Wolfowitz Test } & Posttest - Pretest \\
\hline$Z$ & $-0,584$ \\
\hline Asymp. Sig. (2-tailed) & 0,559 \\
\hline
\end{tabular}

Table 10 shows a $\mathrm{Z}$ value of $-0,584$ in the $\mathrm{H} 0$ region so that it rejects $\mathrm{H} 1$, which means that the conventional model was not effective against mathematical reflective thinking abilities. It could be seen that the treatment of different learning models had different impacts. In the experimental class, using the computer-based, resulted in ineffectiveness. On the other hand, it was not the same as the conventional learning model.

Based on the research done in the experimental class and the control class, they answered the hypothesis testing section presented in the introduction section. Specifically, table 9 answers whether the computer-assisted Drill Model learning was effective against students' mathematical reflective thinking skills. The result was that the computer-assisted Drill learning model is effective against students' mathematical reflective abilities. Meanwhile, table 10 confirms whether conventional model learning was effective against students' mathematical reflective thinking abilities. It showed that conventional learning models were not effective against reflexive thinking skills. The comparison of results in tables 9 and 10 directly answers the third hypothesis. The Drill learning model was better than the conventional learning model for students' reflective thinking skills if learning was done online.

\section{Discussion}

The pretest on the experimental class revealed to us that the mean score of reflective thinking was 63,67 in which was a fair position. The pretest depicts the students' ability to think reflectively using face to the face learning model. The posttest result of the experimental class revealed a score as much as 79,63 with the high category. The result of the posttest revealed success using the computer-based drilling model through the online class as has been shown by the previous research that the drilling model was effective [7]-[9], [22]-[27]. The different basic finding was that the model being employed in this research is online media. It indicated that the drilling model was effective to be used both online and face to face classes. However, some research proved that the drill was not better than the team assisted the individualization learning model and the 
use of GeMA Method [28], [29]. However, the team assisted individualization was higher due to the less support of the computer or online media.

The mean score of the pretest related to the mathematical reflective thinking ability was 71,94 with the category of high. That result was the conventional model or face to face classroom activity. It was also shown by the previous research, which stated that the conventional model would be effective and efficient and could develop mathematical learning success [11], [30], [31]. However, the posttest result on the control class revealed the otherwise result. After it had been treated conventional learning online, it revealed the decreasing score of reflective thinking as much 69,02 of the fair category. It depicts us the conventional online learning was not effective in developing the ability to think reflective mathematics. Together with that fact, the previous research revealed that the conventional model was not better than the inquiry [18], [32].

The computer-based drill model would be effective if conducted with the online system due to the teacher-centered. Teachers were more of the facilitator in the process of learning. It was expected that students would get a better understanding of Math during the teaching and learning process. The model of conventional was the teacher-centered; it required the face to face and direct teacher demonstration. If it was conducted online, it found obstacles due to teacher's difficulties in attaching students.

The contribution of the research results was as a recommendation for teachers to use online learning models. The Drill learning model was very effective in learning during the Covid-19 pandemic. Other findings confirm that the drill learning model was very good for improving students' mathematical reflective abilities in online learning. An interesting topic discussed in this research was the development of teaching materials or learning media used in special online learning using the drill learning model.

\section{$5 \quad$ Conclusion and Future Work}

Based on this research, it could be concluded that (1) Computer assisted Drill model was effective against mathematical reflective thinking skills, (2) Conventional computer-assisted model was not effective against mathematical reflective thinking skills, (3) Computer assisted Drill model was more effective than conventional model in mathematical reflective thinking ability.

By considering the effective learning steps, the computer-based drill learning model would be able to develop students' mathematical reflective thinking. This computerbased learning matched to be used in this pandemic of Covid-19. However, the conventional learning model, which was conducted online, would not be effective in developing students' ability to think reflective since the conventional was fit to be conducted face to face. So, for the future, teachers could also develop the computer-based drill model, which was cooperative learning to attain the learning goals.

\section{Acknowledgement}

We were grateful to the experts for their appropriate and constructive suggestions to improve this template. Universitas PGRI Yogyakarta and LPPM had facilitated the 
authors to conduct and complete this research. The SMP Muhammadiyah 3 Yogyakarta principal gave permission and place to the author to carry out this research. And, for all those people who generously gave of their time and insights during the writing process And, for all those people who helped in the writing process.

\section{$7 \quad$ References}

[1] C. W. Morfi et al., "Kajian Terkini Coronavirus Disease 2019 (COVID-19) [Coronavirus Disease 2019 (COVID-19) Recent Studies], J. Ilmu Kesehat. Indones., vol. 1, no. 1, pp. 18, 2020, [Online]. https://doi.org/10.25077/jikesi.vli1.13

[2] T. Nurhayati and R. H. S. Aji, "Emansipasi Melawan Pandemi Global: Bukti Dari Indonesia [Emancipation Against Global Pandemic: Evidence from Indonesia]," ADALAH, vol. 4, no. 1, pp. 81-92, 2020, doi: 10.15408/adalah.v4i1.15468.

[3] G. D. Rubin et al., "The Role of Chest Imaging in Patient Management during the COVID19 Pandemic: A Multinational Consensus Statement from the Fleischner Society," Chest, no. May, pp. 1-11, 2020, doi: 10.1016/j.chest.2020.04.003.

[4] I. Syawfi, "Implikasi Pandemi COVID-19 terhadap Hubungan Internasional: Menuju dunia Paska-Liberal [Implications of the COVID-19 Pandemic for International Relations: Towards a Post-Liberal world],” J. Ilm. Hub. Int., vol. Khusus, no. April, pp. 23-29, 2020, https://doi.org/10.26593/jihi.v1i1.3864.23-29.

[5] D. R. Buana, "Analisis Perilaku Masyarakat Indonesia dalam Menghadapi Pandemi Virus Corona (Covid-19) dan Kiat Menjaga Kesejahteraan Jiwa [Analysis of Indonesian People's Behavior in Facing the Corona Virus (Covid-19) Pandemic and Tips for Maintaining Mental Well-being," SALAM J. Sos. dan Budaya Syar-i, vol. 7, no. 3, 2020, https://doi.org/10. 15408/sjsbs.v7i3.15082

[6] D. E. Barnett, "Online adjunct faculty: A quantitative examination of the predictive relationship between leadership and job satisfaction,” Int. J. Res. Educ. Sci., vol. 4, no. 1, pp. 226236, 2018, https://doi.org/10.21890/ijres.383159

[7] Y. Kurniawan, "Peningkatan kemampuan pemecahan masalah matematik siswa melalui pembelajaran dengan menggunakan metode drill [Improving students' mathematical problem-solving abilities through learning by using the drill method]," J. Penelit. Pendidik. dan Pengajaran Mat., vol. 2, no. 1, pp. 75-86, 2016, [Online]. Available: http://jurnal.unsil.ac.id/index.php/jp3m/article/view/Yun21.https://doi.org/10.37058/jp3m.v3i2.407

[8] L. Saparwadi, "Efektivitas Metode Pembelajaran Drill dengan Pendekatan Peer Teaching Ditinjau dari Minat dan Prestasi Belajar Matematika Siswa [The Effectiveness of Drill Learning Method with Peer Teaching Approach Judging from Students' Mathematics Interest and Achieve," J. Didakt. Mat., vol. 3, no. 1, pp. 39-46, 2016, doi: 10.24815/ jdm.v3i1.4304. https://doi.org/10.31219/osf.io/jtmsv

[9] N. Wahyuni, "Penggunaan metode drill dalam pembelajaran matematika [The use of drill methods in learning mathematics]," in Prosiding Seminar Nasional, 2013, vol. 02, pp. 399 406, [Online]. Available: http://journal.uncp.ac.id/index.php/proceding/article/view/576.

[10] E. Kumalasari, "Perbedaan hasil belajar matematika siswa yang diajar dengan menggunakan metode drill dan ekspositori [Differences in student learning outcomes in mathematics taught by using drill and expository methods]," J. Penelit. Pendidik. dan Pengajaran Mat., vol. 2, no. 1, pp. 21-28, 2016. https://doi.org/10.24114/jptk.v19i1.7155

[11] I. San and A. Kis, "Effect of traditional methods in geometry and numbers learning domains on academic achievement: A meta-analysis study,” Int. J. Res. Educ. Sci., vol. 4, no. 2, pp. 544-554, 2018, https://doi.org/10.21890/ijres.428950

[12] K. E. Lestari and M. R. Yudhanegara, Penelitian Pendidikan Matematika. Bandung, Jawa Barat, Indonesia: PT Refika Aditama., 2017. 
[13] D. A. Istikomah and P. Jana, "Mathematical Prolem Solving Ability in Apos Modified Learning Model (M-APOS)," J. Phys. Conf. Ser., vol. 1254, no. 1, pp. 1-6, 2019, https://doi.org/10.1088/1742-6596/1254/1/012071

[14] J. Jaenudin, H. Nindiasari, and A. S. Pamungkas, "Analisis Kemampuan Berpikir Reflektif Matematis Siswa Ditinjau Dari Gaya Belajar [Analysis of Students' Reflective Mathematical Thinking Abilities Judged from Learning Styles]," Prima J. Pendidik. Mat., vol. 1, no. 1, pp. 69-82, 2017, https://doi.org/10.31000/prima.vli1.256

[15] O. S. Marhamah, I. Nurlaelah, and I. Setiawati, "Penerapan Model Argument-Driven Inquiry (Adi) Dalam Meningkatkan Kemampuan Berargumentasi Siswa Pada Konsep Pencemaran Lingkungan Di Kelas X Sma Negeri 1 Ciawigebang," Quagga J. Pendidik. dan Biol., vol. 9, no. 02 , p. 45,2017 , https://doi.org/10.25134/quagga.v9i02.747

[16] E. Cener, I. Acun, and G. Demirhan, "The Impact of ICT on Pupils' Achievement and Attitudes in Social Studies,” J. Soc. Stud. Educ. Res., vol. 6, no. 1, pp. 190-207, 2015, https://doi.org/10.17499/jsser.67856

[17] H. Z. Sun-Lin and G. F. Chiou, "Effects of gamified comparison on sixth graders' algebra word problem solving and learning attitude," Educ. Technol. Soc., vol. 22, no. 1, pp. 120 130, 2019, [Online]. Available: https://drive.google.com/open?id=1sEbYGokaatw8AeLWbp5eZIspyu9ZGT9.

[18] K. Salim and D. H. Tiawa, "Implementation of structured inquiry-based model learning toward students' understanding of geometry," Int. J. Res. Educ. Sci., vol. 1, no. 1, pp. 75-83, 2015, https://doi.org/10.21890/ijres.70396

[19] Ö. Korkmaz, M. Kösterelioğlu, and M. Kara, "A validity and reliability study of the engineering and engineering education attitude scale (EEAS),” Int. J. Eng. Pedagog., vol. 8, no. 5, pp. 44-57, 2018, https://doi.org/10.3991/ijep.v8i5.8667

[20] Ö. Korkmaz and M. K. Korkmaz, "A Validity and Reliability Study of the Basic Electronics Skills Self-Efficacy Scale (BESS)," Int. J. Eng. Pedagog., vol. 6, no. 4, p. 30, 2016, https://doi.org/10.3991/ijep.v6i4.6168

[21] D. G. H. Divayana, A. Adiarta, and I. Gede Sudirtha, "Instrument's development of tri kaya Parisudha-based countenance model in evaluating the blended learning," Int. J. Eng. Pedagog., vol. 9, no. 5, pp. 55-74, 2019, https://doi.org/10.3991/ijep.v9i5.11055

[22] C. Fransiska, R. Masykur, and F. G. Putra, "Analisis Kemampuan Pemecahan Masalah Matematis: Dampak Metode Drill ditinjau dari Gaya Belajar,” Desimal J. Mat., vol. 2, no. 2, pp. 131-140, 2019, https://doi.org/10.24042/djm.v2i2.4147

[23] A. Hadi, "Perbandingan Hasil Belajar Matematika Siswa yang Diajar Dengan Metode Drill dan Metode Ekspositori pada Kelas VII SMP Negeri 3 Makassar [Comparison of Student Mathematics Learning Outcomes Taught by Drill Method and Expository Method in Class VII of SMP N," vol. 2, no. 1, pp. 18-26, 2019. https://doi.org/10.24114/seipgsd.v7i1.6848

[24] H. Hermaniah, "Studi Perbandingan Pembelajaran Yang Menggunakan Metode Small Group Discussion Dengan Metode Drill Pada Mata Pelajaran Matematika Kelas III MIN Pemurus Dalam Banjarmasin," Al Adzka J. Ilm. Pendidik. Guru Madrasah Ibtidaiyah, vol. 7, no. 1, pp. 121-144, 2017, doi: http://dx.doi.org/10.18592/aladzkapgmi.v7i1.2025. https://doi.org/10.18592/aladzkapgmi.v9i2.3377

[25] F. Artanti and T. K. Lestari, "Matematika Siswa Dengan Menggunakan Model," in Konferensi Nasional Penelitian Matematika dan Pembelajarannya II (KNPMP II), 2017, no. 18 Maret 2017, pp. 290-300, doi: https://doi.org/10.31932/jpdp.v2i1.25.

[26] S. Saprudin and F. Hamid, "Penggunaan Multimedia Interaktif Model Drill and Practice Materi Fluida Dinamis Untuk Meningkatkan Penguasaan Konsep Siswa Sekolah Menengah Atas (SMA) [Use of Interactive Multimedia Drill Models and Dynamic Fluid Material Practices to Enhance the Mastery," in Prosiding Seminar Nasional Fisika (E-JOURNAL) SNF2018,2018,vol.VII,pp.SNF2018-PE-144-SNF2018-PE-151, https://doi.org/10.21009/03.snf2018.01.pe.19 
[27] A. E. Soponyono, K. Sinaga, and J. Seleky, "Perbandingan penerapan metode drill dan resitasi terhadap hasil belajar kognitif matematika siswa kelas XI IPA di SMA ABC Cikarang [A Comparison of The Implementation Of Drill And Recitation Methods Toward Grade 11 Science Students' Cognitive Achievement," JOHME J. Holist. Math. Educ., vol. 1, no. 2, pp. 81-92, 2018, https://doi.org/10.19166/johme.v1i2.795

[28] B. J. Tama, "Perbedaan Hasil Belajar Matematika Melalui Metode Team Assisted Individualization Dan Metode Drill," J. SAP, vol. 1, no. 3, pp. 322-332, 2017, https://doi.org/10.30998/sap.v1i3.1303

[29] F. A. Yudha, E. Azhar, and W. Wahidin, "Perbedaan kemampuan pemecahan masalah matematis siswa dengan menggunakan metode gema dan metode drill 1," in Prosiding Senamku: Seminar Nasional Pendidikan Matematika UHAMKA, 2018, vol. 01, pp. 191204,[Online].Available:https://journal.uhamka.ac.id /index.php/senamku/article/view/2758. https://doi.org/10.24114/jpmi.v3i2.8889

[30] E. R. Dewi, "Metode Pembelajaran Modern Dan Konvensional Pada Sekolah Menengah Atas," Pembelajar J. Ilmu Pendidikan, Keguruan, dan Pembelajaran, vol. 2, no. 1, p. 44, 2018, https://doi.org/10.26858/pembelajar.v2i1.5442

[31] I. Sakti, "Pengaruh Media Animasi Fisika dalam Model Pembelajaran Langsung (direct instruction) terhadap Minat Belajar dan Pemahaman Konsep Fisika Siswa di SMA Negeri Kota Bengkulu," Pros. Semirata FMIPA Univ. Lampung, 2013, vol. 1, no. 1, pp. 493-498, 2013. https://doi.org/10.22611/jpf.v4i1.2568

[32] P. Jana and E. Supiati, "Efektivitas model problem-based learning ditinjau dari kemampuan pemecahan masalah matematika," J. Mercumatika J. Penelit. Mat. dan Pendidik. Mat., vol. 3, no. 2, pp. 88-93, May 2019, https://doi.org/10.26486/jm.v3i2.745

\section{Authors}

Padrul Jana is a lecturer Department of Mathematics Education, Faculty of Teacher Training and Education, Universitas PGRI Yogyakarta. Jl. PGRI I No. 117, Sonosewu, 55182, Yogyakarta, Indonesia. Teaching and research activities on participating in the application and development of learning models. e-mail: padrul.jana@upy.ac.id

Nurchasanah is a researcher in the Department of Mathematics Education, Faculty of Teacher Training and Education, Universitas PGRI Yogyakarta. Jl. PGRI I No. 117, Sonosewu, 55182, Yogyakarta, Indonesia.

Syita Fatih 'Adna is a lecturer Department of Mathematics Education, Faculty of Teacher Training and Education Universitas Pekalongan, Indonesia. J1. Sriwijaya No.3, Bendan, Kec. Pekalongan Barat, Kota Pekalongan, Jawa Tengah 5111.

Article submitted 2020-06-23. Resubmitted 2021-02-02. Final acceptance 2021-02-02. Final version published as submitted by the authors. 